\title{
Föräldraskap och internet Nya mötesplatser och informationsvägar kring det senmoderna föräldraskapet
}

\author{
LARS PLANTIN \& KRISTIAN DANEBACK
}

Internet har idag blivit en allt viktigare mötesplats för många föräldrar eller blivande föräldrar där man söker stöd och information kring föräldraskapet. Men, vad söker de för slags information på nätet och vilken betydelse har detta stöd för föräldrarna?

\section{Inledning}

Det finns idag en nästan obegränsad tillgång till kunskap och information kring det senmoderna föräldraskapet. Det mediala utbudet av böcker, föräldratidningar och tv-program ökar i sådan takt att det är svårt att överblicka. Livsstilsmagasinen som riktar sig till föräldrar specialiserar sig alltmer för att synas i det ökade bruset av familj och föräldralitteratur; nu senast startades tidningen Äventyrliga föräldrar för föräldrar som vill satsa på ovanliga resor eller aktiviteter med sina barn. Under en vanlig vecka kan vi också

Lars Plantin, docent, Enheten för socialt arbete, Malmö högskola

Kristian Daneback, docent, Institutionen för socialt arbete, Göteborgs universitet räkna in ett antal olika TV-program som har fokus på barn och föräldraskap: Nannyakuten, Dr. Phil, Om familj eller Ett fall för Louise. Föräldraskapet har alltså utvecklats till en kommersiell industri där tips, råd och anvisningar förmedlas i en aldrig sinande ström. Budskapen är emellertid inte konsistenta utan skiftar över tid; det som tidigare var en sanning kring amning, sovställningar eller kostvanor är kanske idag helt felaktigt. Råden växlar även mellan olika experter samtidigt som mycket av informationen har en stark betoning på risk och faror (Beck, 2000). Dagens föräldrar har därför kommit att karaktäriseras i termer av en ökad individualisering, osäkerhet, reflexivitet och riskmedvetenhet (Bäck-Wiklund \& Johansson, 2003; Beck, 2000). 
Det ökade behovet av att söka information kring föräldraskapet kan också härledas till ett förändrat stöd från de egna generationsleden. I den snabba kunskapsutvecklingen har en del av de egna föräldrarnas kunskaper på området blivit föråldrade (O'Connor \& Madge, 2004) samtidigt som släktskapsbanden kommit att präglas av en allt större frivillighet. Giddens (1996:91) beskriver dagens släktskapsrelationer som "framförhandlade» relationer vars styrka snarare bygger på upplevelsen av kvalité än på tradition och ekonomiskt beroende. Att söka stöd i föräldrablivandet hos de egna föräldrarna är alltså inte givet utan endast en möjlighet bland många andra.

Parallellt med denna utveckling har flera forskare pekat på hur familjen som samlevnadsform och begrepp förändrats över tid (Roman, 2004; Castells, 1997). Bäck-Wiklund \& Johansson (2003) menar exempelvis att det senmoderna familjelivet inte längre kan betecknas som en sluten social enhet utan snarare som ett "nätverk" av nära relationer. Globaliseringen, det ökade antalet separationer och det starkt växande antalet ombildade familjer har bidragit till denna utveckling med fler "familjemedlemmar" och en större geografisk spridning av de nära relationerna. Den moderna informationsteknologin och internet har i detta avseende blivit allt viktigare för att upprätthålla emotionella band och kommunicera närheten i vardagslivets relationer. Dagens föräldrar får härigenom en större vana i att söka gemenskaper och kommunicera närhet genom att exempelvis använda internet.

\section{Nya möjligheter till stöd och information}

Att internet också har kommit att bli en viktig arena för många föräldrar visar sig tydligt i det snabbt växande antalet webbsidor som inriktar sig på att förse föräldrar med stöd och information kring föräldraskapet. En del av dessa sidor är utpräglade produktsidor som också innehåller information riktade till föräldrar, exempelvis olika blöjtillverkares hemsidor, medan andra är mer renodlade föräldrasidor som består av olika webbfora och "communities», dvs. gemenskaper på nätet, där man kan träffa andra föräldrar för utbyte av erfarenheter. En av de största webbplatserna i Sverige är Familjeliv.se som har ca 120000 medlemmar och ca 250000 unika besökare varje vecka. Webbplatsen erbjuder en del artiklar med fakta och information, men är framför allt ett exempel på ett forum där föräldrar kan utbyta erfarenhetsbaserad information kring barn och föräldraskap. I dagsläget (februari, 2010) finns det ca 70000 aktiva diskussionstrådar i forumet som behandlar alltifrån graviditeter, förlossningar och amning till barnuppfostran eller sorgen efter ett förlorat barn. Då skall man veta att trådarna automatiskt stängs ner efter 3 månader för att behålla en hög aktivitet i kommunikationen. Många besökare ägnar sig endast åt så kallad "lurking» dvs. man följer passivt diskussionerna i forumet, men ett stort antal är mycket aktiva i kommunikationen.

Inne på diskussionsforumet sker såväl fria diskussioner, där man riktar sig till alla deltagare, som mer organiserade gruppdiskussioner där man samlas kring ett visst 
tema. Eftersom sidan drivs av ett privat företag har den många länkar till reklam för olika företag kring hälsa, skönhet och mode. Ett tidstypiskt tecken på det fenomen som brukar benämnas mediekonvergens, dvs. medier som flyter in i varandra (Jenkins, 2006). I vissa avseenden handlar det om att generera trafik till sidor där besökaren ska betala för någon typ av tjänst (ett närliggande exempel på hur detta går till finns beskrivet i Månsson \& Söderlind 2004).

En annan typ av föräldrasidor finns i de mer renodlade informationsplatserna för faktabaserad kunskap kring barn och föräldraskap. Ett sådant exempel är GrowingPeople.se som har ambitionen att vara en "kunskapskälla» för föräldrar men också för professionella som arbetar med barn, familjeliv och föräldraskap. Webbplatsen drivs av ett landsting och regionägt företag och består av mer än 8000 olika informationssidor som beskriver alltifrån graviditet, barns utveckling och familjerelationer till kost, motion och skolgång. Varje vecka besöks webbplatsen av ca 70000 besökare och enligt företaget är många av dessa professionella som arbetar med barn. För dessa finns en specifik avdelning där de, mot en årlig avgift, kan få tillgång till information, riktlinjer och rekommendationer. Bland annat ges man tillgång till en nationell handbok för barnhälsovård och ett forum för diskussioner med kolleger.

För föräldrar finns det inte bara ett forum för kommunikation med andra föräldrar utan också en »frågelåda» där man ges möjligheten att ställa frågor till professionella inom olika områden. I nuläget har företaget ett hundratal experter knutna till sig som årligen svarar på ca 3000 frågor från föräldrarna.
Båda dessa webbsidor kan tjäna som tydliga exempel på Jenkins (2006) tankegångar om hur information idag inte längre förmedlas via envägskommunikation eller utifrån ett »uppifrån-ochned-perspektiv«, utan snarare via olika kommunikationsvägar och med en ökad interaktivitet med användarna. Familjeliv. se är den av de två sidorna som starkast domineras av interaktivitet och kommunikation mellan användarna. Genom de omfattande forumdiskussionerna är föräldrarna här i lika hög grad producenter som konsumenter av information. Growingpeople.se har däremot, genom den betydligt större mängden informationssidor och lägre intensiteten i de interaktiva kanalerna, en tydligare prägel av sändarperspektiv från professionell till förälder. Men vad innebär egentligen denna utveckling för dagens föräldrar eller blivande föräldrar och vilken betydelse har stödet på internet för föräldrarna? Eller mer konkret, vad betyder de olika former av sociala nätverk som skapas på internet för föräldrarna och hur använder man överhuvudtaget internet som kunskapskälla eller bas för utbyte av olika erfarenheter kring föräldraskapet? Skapar informationstillgängligheten trygghet eller oro; lösningar eller problem? Syftet med denna artikel är att belysa just dessa olika kvalitativa aspekter på föräldrars användande av internet som en arena för stöd i sitt föräldraskap. Fokus i artikeln är alltså i huvudsak på föräldrarna och deras upplevelser och ageranden snarare än på tekniken och internet som arena. 


\section{Tidigare forskning}

Det finns idag mycket lite forskning som undersökt hur svenska föräldrar eller blivande föräldrar söker stöd och information på nätet eller vilken betydelse detta har för dagens föräldrar. År 2002 genomfördes emellertid en enkätstudie med 2499 respondenter på webbsidan „FöräldraNätet « ${ }^{1}$ (Sarkadi, 2003). En överväldigande majoritet av deltagarna, 95 procent, var kvinnor. Medelåldern var knappt 31 år och 2/3 hade en inkomst i nivå med eller strax under det nationella genomsnittet. Studien visade även att en majoritet av föräldrarna använde FöräldraNätet som en första instans när de behövde råd och information, detta oavsett utbildningsnivå. Webbplatsen fungerade emellertid inte bara som informationskälla utan upplevdes också ha en viktig funktion som socialt forum och stöd. Framför allt ensamstående, lågutbildade och låginkomsttagare upplevde bättre socialt stöd via webbsidans chattmöjligheter jämfört med användare från högre sociala skikt. Detta visar, menar Sarkadi \& Bremberg (2005), att internet fyller en viktig funktion för föräldrarna och att det sannolikt kommer att vara en resurs i framtida hälsorelaterat arbete rörande barn och spädbarn.

År 2008 gjorde Folkhälsoinstitutet en uppföljning av föräldrars erfarenheter och intresse av olika former av föräldrastöd (Eriksson \& Bremberg, 2008). Kartläggningen visar att många föräldrar, framför

1 "FöräldraNätet" har ändrat namn och heter idag "Allt för föräldrar" (alltforforaldrar.se). allt de yngre, använder internet som stöd i föräldraskapet. Av de yngre respondenterna besökte 54 procent olika föräldrasidor och de flesta föräldrarna med spädbarn var positiva till att få mer föräldrainformation via internet och delta i webbaserade föräldrakurser.

Den internationella forskningen på området är emellertid mer omfattande, både till omfång och djup. En systematisk genomgång av fem olika artikeldatabaser (Plantin \& Daneback, 2009; Daneback \& Plantin, 2008) visar att forskningsfältet etablerades i USA vid slutet på 1990-talet och hade då en tydlig koppling till medicinsk klinisk forskning. De första artiklarna undersökte främst webbsidor som riktade sig till föräldrar vars barn hade drabbats av olika sjukdomar eller handikapp. Därefter har forskningsfältet breddats och antagit en mer tvärvetenskaplig karaktär. En rad olika frågeställningar har undersökts men främst har fyra olika teman dominerat forskningen över tid: analyser av olika webbsidor, föräldrars användarbeteenden, stödgrupper på nätet samt utvärderingar av olika interventioner riktade till föräldrar på nätet.

Det första temat har i huvudsak haft fokus på en inventering och analys av användbara webbsidor för föräldrar. Samtidigt har analyserna också intresserat sig för kvalitén på den information som sprids, dvs. man har undersökt om den överensstämmer med nationella eller globala riktlinjer (Dolev \& Zeedyk, 2006). Grovt sett visar det här området att kvalitén på den information man riktar till föräldrar varierar stort mellan olika webbsidor. Därför drar många studier slutsatsen att det är av yttersta vikt att professionella som arbetar 
med föräldrar kan rekommendera kvalitetsmässigt bra webbsidor (Carter, 2007).

Det andra temat rör föräldrars användarbeteende på nätet och har främst fokus på hur, när och var föräldrar söker information på nätet. Olika studier visar samstämmigt att en stor andel av dagens förstagångsföräldrar i västvärlden, inte minst mödrar, vänder sig till nätet som en primärkälla för information kring föräldraskapet (Allen \& Reine, 2002). Merparten besöker olika föräldrasidor en eller flera gånger i veckan och oftast väljer man webbplatser med möjlighet att utbyta erfarenhetsbaserad information (Madge \& O'Connor, 2006). Detta då webbsidor som enbart är faktaorienterade uppfattas som svårförståeliga och tråkiga i sin utformning (Berland et al., 2001).

Problemet med att många webbsidor med hälsoinformation är svårförståeliga och ofta kräver en högre utbildningsnivå anknyter till frågan om sociala klasskillnader på nätet. I den internationella litteraturen har man främst diskuterat klasskillnaderna på nätet utifrån tillgången till internet. Man konstaterar att de som har tillgång till internet tillhör de mer etablerade grupperna i samhället. De som söker information kring barn, hälsa och föräldraskap är exempelvis främst vita medelklasskvinnor i 30-årsåldern (Fox, 2005). Samtidigt visar allt fler studier att klasskillnaderna tycks minska i detta avseende (Eurostat, 2007), vilket också sätter sina avtryck på föräldrasidorna. Russell (2006), som undersökt den engelska föräldrasidan Netmums.com, fann exempelvis att 40 procent av besökarna kom från familjer med lägre inkomster. Liknande resultat återfinns $\mathrm{i}$ andra internationella studier (Dunham, 1998) men också i den tidigare nämnda svenska studien av Sarkadi (2003), där en majoritet av användarna hade en inkomst i nivå med eller under det nationella genomsnittet.

$\mathrm{Av}$ den tidigare forskningen tycks det alltså som att vi inte längre bara kan diskutera skillnader i social klass på nätet utifrån tillgänglighet utan också bör sätta fokus på andra områden såsom sidornas utformning, språk och läsbarhet, dvs. vem man riktar sig till eller var på nätet olika grupper befinner sig.

Det tredje temat inom forskningen rör föräldrars upplevelser av att aktivt medverka i olika sociala nätverk eller stödgrupper på nätet. Det kan gälla stödgrupper för unga tonårsmammor (Hudson et al., 1999), lesbiska mammor (Lev et al., 2005), fäder (Nicholas et al., 2003) eller föräldrar med psykiska handikapp (Scharer, 2005). Generellt visar denna forskning att föräldrarna upplever det som ett värdefullt stöd att kunna utbyta erfarenhetsbaserad information med andra i en liknande situation (Baum, 2004). Även Drentea \& Moren-Cross (2005) drar denna slutsats men diskuterar föräldrarnas upplevelser av stöd i termer av socialt kapital, dvs. en resurs som skapas genom att man utvecklar fler och tillitsfulla kontakter med andra människor. De fann att de sociala nätverk föräldrarna bygger upp på nätet, där de ger både känslomässigt stöd och konkreta råd i olika situationer, genererar ett viktigt socialt kapital som underlättar vardagslivet i föräldraskapet. Generellt saknas det annars studier som har en tydlig teoretisk anknytning när de undersöker föräldrars kommunikation på internet. Vi 
har dock noterat att det utanför föräldraforskningen, i forskningen kring andra sociala nätverkssidor som Facebook.com eller MySpace.com, finns fler studier som undersökt nätkommunikationen med hjälp av olika teoretiskt perspektiv (se exempelvis Boyd \& Ellison, 2007; Mazer et al, 2007).

Det fjärde och sista temat i forskningen kring föräldraskap och internet har betonat professionellas interventioner på nätet. Redan i slutet på 1990-talet utvärderades olika försök att föra ut hälsoinformation till föräldrar över nätet (Downing et al, 1999) och man har även undersökt möjligheterna att lägga ut olika utbildningseller träningsprogram kopplat till förebyggande hälsovård (Brown et al., 2004). De flesta interventioner som har undersökts beskrivs som övervägande framgångsrika. Hudson et al. (2003) har exempelvis genomfört en jämförande studie av två olika grupper av fäder - en som deltog i en webbaserad föräldrautbildning och en som endast erbjöds deltagande i den reguljära mödra- och barnhälsovårdsutbildningen - som visar mycket positiva resultat av nätbaserade insatser. De fäder som deltog i internetutbildningen rapporterade en tydligare ökning av både kompetens och självtillit under mätperioden än fäderna i jämförelsegruppen.

Utöver att vissa interventioner ger bättre effekt över nätet lyfter många studier också fram att dessa interventioner är kostnadseffektiva, når ut till fler föräldrar och har högre tillgänglighet (Mankuta et al., 2007).

Så här långt kan vi alltså konstatera att den internationella forskningen kring föräldraskap och internet vuxit betydligt i omfång under det senaste decenniet. Mycket av forskningen har varit deskriptiv och kartläggande men ofta saknat ett teoretiskt perspektiv som kan ge en bredare förståelse för betydelsen av föräldrastödet på nätet. Inte minst i svenskt hänseende saknas det forskning som både tydligt undersöker hur föräldrar använder stödet på nätet och de kvalitativa aspekterna av dessa möjligheter.

\section{Studiens upplägg och genomförande}

Hösten 2008 genomfördes 18 kvalitativa intervjuer med mammor som alla hade erfarenhet av att söka stöd och information i sitt föräldraskap på nätet. Mot bakgrund av att tidigare forskning visat att det främst är blivande eller nyblivna förstagångsföräldrar, företrädesvis mödrar, som är aktiva i att söka föräldrastöd på nätet (Allen \& Reine, 2002) vände vi oss primärt till en mödravårdscentral för att få informanter. Under två veckors tid tillfrågade en barnmorska de föräldrar hon kom i kontakt med om deltagande samt överräckte tryckt information om projektet. Några föräldrar blev dock inte tillfrågade, främst personer med lässvårigheter och personer som inte behärskade svenska språket. Vid intresse för att medverka överlämnades telefonnummer till oss som sedan ringde upp och avtalade tid för intervju. Redan efter ett mindre antal intervjuer framgick det dock att några mödrar hade väldigt begränsad erfarenhet av att söka stöd och information kring föräldraskapet på nätet. Då studien hade för avsikt att undersöka vad 
föräldrarna söker för information på nätet och vilken betydelse det har för det egna föräldraskapet var det angeläget att finna föräldrar med stor erfarenhet av att söka stöd på nätet. Därför rekryterades också intervjupersoner via respondenternas sociala nätverk (s.k. snöbollsteknik). Totalt sett rekryterades 7 intervjupersoner via mödravårdscentralen och 11 personer med hjälp av snöbollstekniken.

Samtliga intervjuade var kvinnor och knappt hälften var förstagångsmammor. Medelåldern hos intervjupersonerna var 32 år, med en spridning i åldrar mellan 25 och 39 år. Alla utom en hade högskoleeller universitetsutbildning. Den könsmässiga snedfördelningen kan förmodligen främst förstås utifrån att väldigt få män följer med sin partner till mödravårdscentralen under graviditeten, inte minst vid de återkommande rutinundersökningarna, samt att mer än 90 procent av besökarna eller medlemmarna på olika föräldrasidor är kvinnor (Sarkadi \& Bremberg, 2005). Att i stort sett samtliga intervjupersoner hade högre utbildning kan ha flera förklaringar. Litteraturgenomgången visar att föräldrar med högre utbildning har en större vana att söka hälso- och föräldrainformation (Fox, 2005), även om skillnaderna mellan olika grupper tycks minska (Eurostat, 2007; Russell, 2006). Att vi valde att vända oss till en mödravårdscentral vars upptagningsområde präglas av en hög utbildningsnivå har förmodligen också påverkat urvalet. Samtidigt rekryterades inte alla intervjupersonerna från mödravårdscentralen utan också via snöbollsteknik. Denna teknik har emellertid en begränsad potential i att skapa socioekonomisk spridning i materialet eftersom människors sociala nätverk ofta präglas av homogenitet i detta avseende (Bourdieu, 1988). Att urvalet nästan helt kom att domineras av högutbildade kvinnor föranledde diskussioner om åtgärder för att skapa en större variation. Vi konstaterade dock att vårt urval slutligen blev ett "typurval" för föräldrar på nätet och därmed fann vi ingen anledning till korrigerande åtgärder.

Intervjuerna genomfördes med hjälp av en intervjuguide med fokus på frågor om hur man använder nätet i föräldraskapet, föräldrarnas beteende on-line samt upplevelser och erfarenheter av att söka stöd eller information på nätet. Av de 18 intervjuerna gjordes 14 face-to-face och 4 via e-post. Alla intervjuer spelades in på band och varade ca 1,5 timme. De intervjuer som gjordes via e-post byggde på att intervjuaren sände ett antal frågor som besvarades av informanterna. I något enstaka fall följdes otydliga svar upp med ytterligare frågor. I analysen av materialet har vi sökt efter olika mönster och teman som karaktäriserat både de enskilda intervjuerna och materialet som helhet. Mer konkret har det inneburit att varje intervju först ordnats efter intervjuguidens olika tematiserade frågeområden och därefter koncentrerats och bearbetats till mer koncisa resonemang. Successivt har det på så sätt framträtt olika teman som ställts i relation till teman i övriga intervjuer. Studien bygger på informerat samtycke och har följt gängse etikregler för humanistisk och samhällsvetenskaplig forskning. 


\section{Att bli förälder på nätet}

\section{Om planering och blivande gravida föräldrar}

Även om de flesta unga vuxna idag ser positivt på att skaffa barn så gör man det allt senare i livet. Medelåldern för föräldrablivandet är idag nästan 29 år för kvinnor och drygt 31 år för män (SCB, 2009). Innan barnafödandet prioriterar många att utbilda sig och att etablera sig på både bostads- och arbetsmarknaden. Denna period sträcks ut under en allt längre tid vilket också får till följd att barnafödandet blir alltmer planerat. Flera olika "karriärer" skall samordnas parallellt och idag talar man oftare om att "skaffa sig barn" snarare än att "få barn" (Ungdomsstyrelsen, 2003).

Dessa uttryck för val och planering kring föräldraskapet framkommer också tydligt i vårt material. Flera av informanterna har börjat söka information kring barn och föräldraskap långt innan de varit gravida. Orsakerna har varit flera men önskan om att kunna styra barnafödandet till rätt tillfälle i livet har varit viktigt för de flesta informanterna. Det skall inte ske för tidigt i livet då det kan återverka på utbildningen och möjligheten att få jobb. Samtidigt får man inte bli för gammal eftersom det kan påverka möjligheten att bli gravid. För att fånga detta "rätta» tillfälle bör man, som en av informanterna uttryckte det, "vara så förberedd som möjligt«. Någon av intervjupersonerna började besöka föräldrasidorna på internet för att ta reda på "hur lång tid efter man slutat skydda sig som man kan bli gravid«; andra sökte efter information om »hur många månader det tar innan man blir gravid» eller "vad som egentligen sker vid befruktningen [..] i de olika stadierna». I några fall framkom också hur behovet av att tidigt planera sin graviditet kan handla om att försöka optimera förutsättningarna för det fiktiva barnet och förverkliga högt ställda förväntningar på det kommande föräldraskapet:

Vi försökte planera graviditeten så att barnet skulle födas så tidigt som möjligt på året så att det skulle få en bra start $i$ livet, alltså vara moget när det börjar skolan. Och så ville vi parera möjligheten att få dagisplats och då borde barnet födas $i$ majjuni eftersom det är lättare att få dagisplats $i$ augusti, man fär ju parera det hela med jobbet så att båda sakerna funkar samtidigt (Anna, 36 år)

Även om inte alla intervjupersoner gett uttryck för en så här detaljerad planering av en framtida graviditet, så har de flesta förmedlat en tydlig bild av långsiktig planering kring föräldraskapet. Att bli förälder betecknas som "ett spännande projekt" och det kräver ständiga överväganden för att kunna genomföras på ett optimalt sätt. Valen är många och oron påtaglig:

Det är ju viktigt att ta reda på en massa saker för att kunna säga hur man vill ha sin förlossning alltså om man vill ha epidural eller ej, musik på förlossningen, föda i bassäng eller så, det är ju massor att tänka på (Felicia, 32 år)

Den rigorösa planering som intervjupersonerna här ger uttryck för kan alltså förstås i ljuset av det senmoderna familjeprojek- 
tet där både kvinnor och män gör karriär samtidigt som de måste länka samman sina individuella livslopp till en gemensamhet. Att skaffa barn är något som kräver "timing" och precision för balansen mellan det individuella och gemensamma. Inom paren förekommer därför, som en av respondenterna uttryckte det, "långa diskussioner om hur det kommer att bli att få barn«. Ingenting är givet och framtiden uppfattas som högst möjlig att forma.

Samtidigt leder oron över alla valmöjligheter till ett behov av att också spegla sina funderingar mot fler personer i samma situation. En av intervjupersonerna säger "Man vill kanske få bekräftat att man tänkt eller känner rätt eller så vill man ibland få råd om hur man skall göra». Därför har många valt att söka erfarenhetsbaserad information på föräldrasidornas webbforum. Under avdelningen »Planera barn» ryms en mängd »samtalstrådar" som alla fokuserar på en kommande graviditet. Aktiviteten är hög och bara på föräldrasidan Familjeliv.se öppnas det ca 1600 nya trådar kring detta ämne varje månad och under motsvarande tidsperiod görs det i genomsnitt 34000 inlägg som handlar om att planera barn. Inte sällan går man samman i grupper som stöttar varandra i planeringen av graviditeten. Här diskuteras alltifrån relationer, kostråd och preventivmedel till samlagsfrekvens eller risken för missfall. Grupperna formeras ofta utifrån rena målsättningar och heter exempelvis "vi som skall bli gravida i Juni", "vi som planerar barn till nästa höst" eller »ägglossning 26-27 maj«. I många grupper är det just kvinnans ägglossning som är i centrum för diskussionerna och det är vanligt att man använder sig av en specifik metod,
Fertility friends metoden, för att kartlägga ägglossningen och se vilka dagar i månaden man är mest fertil. Kartläggningen innebär att man dagligen mäter sin egen kroppstemperatur under tiden för ägglossningen och sedan för in resultatet i ett diagram. Man registrerar även humörväxlingar hungerskänslor, känslighet i huden osv. Diagrammen följs och analyseras sedan av deltagarna i gruppen. De som lyckas "plussa", dvs bli gravida, lyckönskas och går vidare till en tråd för gravida medan de andra stannar kvar och ger varandra fortsatt stöd. Stödet betecknas som viktigt för de allra flesta, inte minst för känslan av att man redan är på väg in i föräldraskapet:

Det kanske låter konstigt men vi är ju ett gäng blivande, gravida mammor som umgås och stöttar varandra $i$ vår lilla tråd. Man följer varandra genom glädje och tårar och är som en slags familj, det är väldigt speciellt. Vi är ett kärngäng som hailler ihop även om en del har "plussat" och gått vidare till gravidgrupperna (Jessica, 29 år)

Arbetet med att skapa en föräldraidentitet påbörjas alltså redan långt innan man är gravid. Det sker individuellt och i relation till partnern men också i en kollektiv form där man blir sett gäng blivande gravida mammor». På många sätt kan det här betraktas som ett nytt fenomen då blivande, gravida mammor inte tidigare i historien har haft samma möjlighet att sluta sig samman i större grupper under en längre tid och gemensamt forma en identitet. Tekniken och det sociala livet på föräldrasidornas diskussionsforum skapar goda förutsättningar för detta. Samtidigt 
menar Bauman (2003) att dessa gemenskaper också kan förstås utifrån den senmoderna människans behov av att ständigt pröva olika identiteter och relationer utan att för den skull binda upp sig i långvariga åtaganden. Diskussionerna på nätet gör det möjligt att i ett tidigt skede känna på ansvaret, oron och gemenskapen i föräldraskapet samtidigt som det är möjligt att när som helst dra sig ur och välja en annan väg. En av våra informanter lämnade exempelvis sin grupp av blivande gravida mammor efter några månader;

Jag tröttnade till slut på alla diskussioner och lade hela den här tanken med att skaffa barn på hyllan ett slag, det blev för mycket (Anna 28 år).

\section{Informationsbehov under graviditeten-variationer övertid}

Även om många av våra intervjupersoner har sökt sig till nätets föräldrasidor redan innan de varit gravida så har trots allt de flesta sökt sig dit på allvar först efter graviditetsbeskedet. Att vända sig till nätet har varit en självklarhet då det, som en av informanterna uttryckte det, erbjuder "en ocean av information kring allt man vill veta». Inga böcker eller tidningar, menar man, »kan mäta sig med nätet på det sättet, där finns allt när man vill ha det... dessutom är det ofta mer uppdaterat än böcker». Att nätet också möjliggör en mer personlig och precis information genom olika sökfunktioner och interaktiv kommunikation har framhållits som en stor fördel: »har man ont i högra sidan på bäckenet så söker man på det och får träff, det är helt otroligt». Valet av nätet som informationskanal ligger också nära tillhands då datorn ständigt står på i hemmet och man ändå är on-line i en mängd andra ärenden. Man upprätthåller sociala kontakter med släkt och vänner, sköter sin ekonomi, "Googlar saker» och väljer nätet i första hand när man söker hälsoinformation. „Det går inte att komma fram till vårdcentralen om man ringer så först kollar man på nätet om det är något farligt». Internetanvändningen tycks för många vara så integrerad i vardagen att de har svårt för att uppskatta hur mycket tid de är på nätet. "Man kollar saker hela tiden när man behöver det, går in och ut, det blir aldrig i långa perioder, men kanske 1,5-2 timmar per kväll».

De flesta mammorna har vuxit upp med internet och har alltså en självklar vana att både vara sociala och söka information på nätet. Prensky (2001) benämner denna generation som »digital natives» eller "native speakers" och menar att deras tidiga socialisation på internet skapat ett fundamentalt annorlunda sätt att söka, tänka kring och processa kunskap. Till skillnad från "digital immigrants», som lärt känna internetvärlden senare i livet, vänder de sig exempelvis i första hand till nätet när de söker information om något. När behovet uppstår är de vana att nå informationen snabbt och söker gärna parallellt kunskap på flera olika ställen. Behovet av föräldrainformation kan dock variera mellan olika perioder, något som tydligt avtecknar sig i våra informanters berättelser.

Inledningsvis hämtar man mycket fakta på nätet, exempelvis om barnets utveckling 
eller hur man lindrar illamåendet i början av graviditeten. Man hämtar delvis denna information från föräldrasidorna men också från olika specialiserade sidor/organisationer så som sjukvårdsrådgivningen. se, netdoktor.se eller fass.se. De flesta har i denna fas också varit inne på livsmedelsvekets hemsida för att se vad man bör äta eller inte äta. Några har även sökt på olika hemsidor efter råd om motion. Gemensamt är dock att man samlar på sig mycket fakta för att bekräfta normaliteten i sin graviditet. Många understryker också att tiden direkt efter graviditetsbeskedet är den tid då man söker mest information. Därefter tycks aktiviteten minska något för att sedan öka igen i mitten på graviditeten. I denna fas börjar man leta efter mer erfarenhetsbaserad information gällande förlossningen: man läser förlossningsberättelser eller söker efter tips om hur andra hanterar exempelvis smärtor under graviditeten.

Slutligen tycks informationsinhämtningen öka markant en tid innan förlossningen. Många söker då erfarenhetsbaserad information om foglossning, smärtlindring under förlossningen eller upplevelsen av olika förlossningsmetoder. "Jag blev plötsligt livrädd när jag började tänka på förlossningen så då surfade jag nog 2-3 timmar/ dag" (Elin, 34 år). Samtidigt börjar man besöka olika företagssidor för att få praktisk information om barnvagnar, bärselar eller bilstolar.

Den första tiden efter förlossningen säger sig de flesta ha varit "upptagna med barnet så man hann inte vara på nätet precis». Men efter någon månad ökar informationssökandet igen, då främst med fokus på information om amning, sömn eller barnsjukdomar.
Till viss del söker man också efter erfarenhetsbaserad kunskap om rutiner kring barnet. I intervjumaterialet finns exempel på hur motsättningar kan uppstå på områden där deltagarna har olika åsikter. En informant som inte kunde amma upplevde att hon inte fick stöd när det gällde att flaskmata sitt barn. Alla som deltog i diskussionen förkastade istället flaskmatning, något hon tyckte var mycket jobbigt. Dessutom menar hon att några av hennes inlägg i tråden modererades bort och att vissa åsikter inte är önskvärda eller censureras av dem som står bakom webbplatserna.

När barnen blivit ett år eller äldre fortsätter sökandet i ännu tydligare grad efter både fakta och erfarenhetsbaserad kunskap. Det gäller information kring olika sjukdomar, uppfostran och beteenden. Flera beskriver dock att intensiteten i sökandet minskar efterhand som man känner sig tryggare och har färre frågor. Några övergår istället till att hjälpa andra och nyblivna föräldrar med att besvara frågor. Det kan ske i varierande former: att man skriver enstaka inlägg på offentliga forum, självorganiserar "mentorsgrupper" för blivande föräldrar eller med hjälp av text och foto berättar om sitt vardagsliv som förälder.

Det framgår alltså tydligt $i$ våra intervjuer att mammorna söker mycket information om barn och föräldraskap över nätet, även om informationsbehovet varierar över tid och kan ändra karaktär. Ibland söker man bara efter renodlad fakta och ibland bara efter erfarenhetsbaserad information. Förstagångsmammorna har ett tydligare behov av information än de som har ett eller flera barn sedan tidigare. Möjligheten 
att få ständigt uppdaterad information precis när man behöver det, att kunna söka igenom flera experters hemsidor för råd och vägledning och möjligheten att kunna kommunicera med andra i samma situation är dock centrala drivkrafter i informanternas berättelser. Internet tillgodoser alla dessa aspekter samtidigt och det är svårt, menar Dunham et al (1998:299), att tänka sig "any single community service providing, in such a timely manner, the same diverse amount of information and support on a daily basis".

Sökandet efter erfarenhetsbaserad information sker emellertid på två sätt: antingen genom så kallad "lurking", dvs. man går in i olika trådar och läser vad som skrivs, eller så går man också aktivt in och deltar diskussionerna. Vad föranleder att man övergår från passiv till aktiv i detta avseende och hur upplevs dessa nätgemenskaper?

\section{Gemenskaper på nätet och särskilda behov}

Intervjumaterialet ger många förklaringar till varför man aktivt gett sig in på nätet och deltagit i olika diskussioner. En del informanter menar att de har en vana att diskutera med andra på nätet och att det därför varit naturligt att ställa frågor. Andra har menat att det känts tryggt att prata med någon som har erfarenhet "eftersom det finns så mycket information i omlopp att man inte vet vad man skall tro«. Ytterligare några har menat att de inte haft tillgång till de egna föräldrarna eller nära vänner att diskutera med, medan andra känt att de "ville berätta om vad man varit med om". Behovet av att vilja berätta om exempelvis sin förlossning kan ha olika drivkrafter: dels kan det fungera som en "Rite of passage» $i$ föräldraskapet (van Gennep, 2004) och dels kan det fungera som ett sätt att rekonstruera händelserna i en viktig livserfarenhet (Bylund, 2005). En av våra intervjupersoner uttrycker det som att hon "behövde skriva av sig för att förstå vad som egentligen hände». En annan stark anledning till varför man börjat kommunicera med andra på nätet är plötsliga och ofta negativa händelser kring barnet, både under och efter graviditeten:

När jag fick missfall surfade jag enormt mycket på Familjelivs del "Känsliga rummet". Jag gick med i olika forum, chattade och sökte tröst nästan hela tiden. Jag var sjukskriven och satt ca 4-5 timmarl dag vid datorn och jag gjorde kanske 20-30 inlägg om dagen. Sedan blev jag gravid igen och då blev mitt surfande mer normalt (Annika, 34 år).

En annan informant som också fått missfall menar att kontakterna med sjukvården efterlämnade alltför många obesvarade frågor och därför sökte hon sig till diskussionsgrupperna på Familjeliv.se. "Bara det att någon sa att man kunde få barn igen var otroligt skönt att få höra». Samtidigt betonar hon behovet av "att få älta» sin upplevelse, något som det inte fanns tid med hos sjukvården. Just den obegränsade möjligheten att få diskutera sin situation med andra som har liknande erfarenheter återkommer i de flesta berättelser, inte minst i intervjuerna med de mammor som har förlorat sitt 
barn precis innan eller direkt efter förlossningen. I deras beskrivning kläds tillvaron på nätet i termer av »livsnödvändig", "en fantastisk gemenskap» och som »den bästa terapin«:

när det var som värst ägnade jag ca 6 timmar om dagen till att prata med andra föräldrar inne på Änglarummen eller så surfade jag runt på olika sidor som handlade om sorg, döda barn, stressreaktioner och så. Det hade aldrig gått att ersätta med något annat. Det finns ingen som orkar lyssna på någon $i$ det tillståndet så länge, man behöver bara älta saker om och om igen och då är det skönt att det alltid finns någon därpå nätet (Emma, 31 år)

Återigen tydliggörs fördelarna med den stora tillgängligheten på nätet och möjligheterna att snabbt länka samman personer med liknande erfarenheter. Dygnet runt, kanske mitt i natten när ångesten gnager, finns där någon som är beredd att lyssna och prata, någon som varit med om samma händelse och »vet vad det innebärı. Flera lyfter också fram fördelen med att det ofta är kort startsträcka i samtalet, "man pratar direkt om det som man vill och slipper kringpratet som annars är vanligt i kontakten med andra människor». Överlag uppfattar man det också som svårt att, utanför internet, få tillräckligt stöd i en krissituation och att få prata om sin sorg. Vänner drar sig undan och vill inte störa medan psykologer och kuratorer saknar resurser att svara upp till det stora behovet av att prata:

Jag pratar med en kurator och hon är jätte- bra att prata med. Hon har mycket erfarenhet och har träffat många föräldrar som mist sina barn - men hon har inte varit där, det är en skillnad. Jag känner mycket mer samhörighet med dompå Familjeliv.

Samtidigt menar de flesta att hjälpen från kuratorer eller psykologer är viktig

eftersom de har en mer professionell syn på det hela. För ibland kan allting på tråden bli så himla känslomässigt... men hon (kuratorn) kan se lite mer 'nyktert' på saker, ge mer ledord, du vet säga de där kloka orden (Maja, 33 år).

Några har också påpekat riskerna med att söka stöd på nätet när man är i kris:

Det är för öppet ibland. När man är inne $i$ en kris är det kanske inte alltid så lätt att tänka på hur öppet det är internet. Det är lätt att känna att det här är vår lilla tråd och här är vi och har det mysigt och alla känner varandra och är snälla men hela världen kan ju egentligen komma in på vår tråd(Felicia, 32 år).

På samma sätt som de blivande gravida mammorna och de mer erfarna mammorna vi tidigare diskuterade så formar även dessa mammor en stark kollektiv identitet på nätet. I samtliga intervjuer understryker man den starka gemenskapen på trådarna och talar om sig själv och de andra deltagarna som »änglamammor", ett uttryck som även har internationell spridning ("mothers of angels", se Capitulo, 2004). Behovet av att skapa en kollektiv identitet kan ha flera orsaker men framför allt har kvinnorna 
pekat på hur viktigt det är att få bära eller dela sorgen med andra. Några underströk också behovet av att bekräfta sin identitet som förälder trots att barnet avlidit:

\section{På forumet finns alltid barnen närvarande} och där är man alltid förälder till sitt barn, så är det inte alltid ute $i$ vanliga livet, syns inte barnen fysiskt så finns liksom varken dom eller man själv som förälder (Ebba, 34 år).

Änglamammorna är emellertid inte de enda i vårt material som tydligt söker sig till grupper av föräldrar med liknande erfarenheter för att få stöd. Tvärtom finns det många exempel på mammor som upplever sig "annorlunda" eller att man »inte passar in" i den reguljära synen på det goda föräldraskapet. Det gäller inte bara flaskmatning som tidigare nämndes utan även kvinnor som ville bli kejsarsnittade istället för att föda vaginalt. Ytterligare någon kände sig besviken på mödrahälsovårdens föräldragrupper eftersom »de inte tog upp könsmaktsfrågor, jag skulle vilja ha mycket mer av det». Föräldrasidornas olika samtalstrådar och medlemsforum erbjuder här stora möjligheter för varje förälder att möta likasinnade, normalisera sitt föräldraskap och finna stöd för sin situation.

I många fall stannar nätgemenskaperna inte vid möten på internet utan man träffas även i det vanliga livet. För en del har detta inneburit att man utvecklat mycket nära vänskapsrelationer, för andra en insikt att gemenskapen bäst fungerar på nätet. Ett vanligt problem som uppstår är att graden av öppenhet som man haft i samtalen över nätet minskar när man träffas ansikte mot ansikte "för då måste man leva upp till och stå för allt man har berättat, att man kanske har problem med sin man eller sexlivet eller såu. Därför sägs det att kontakten ibland "svalnar" när man möts utanför nätet och att man tvingas bli "normalt socialt distanserad».

\section{Sammanfattning och slutdiskussion}

Mammorna i vår studie hämtar en mängd information kring barn och föräldraskap på internet. Det gäller alltifrån sjukdomstillstånd och hälsoråd till information om dagis, skola och föräldrapeng. Informationen söker man på olika webbsidor för föräldrar och myndigheters hemsidor. De flesta nöjer sig inte med enbart fakta utan söker även erfarenhetsbaserad information på olika "communitiesu. Många tar del av andras erfarenheter genom att endast läsa och följa samtalen i trådarna medan andra aktivt deltar i kommunikationen.

Behovet av information visade sig dock variera över tid och var som intensivast i början och slutet av graviditeten. För många av informanterna påbörjades informationsinhämtningen redan innan graviditeten, i någon av "planera barn" -grupperna som finns på nätet. Grupperna förmedlar erfarenhetsbaserad information med fokus på fertilitet, reproduktion och det framtida föräldraskapet. Flera av intervjuerna visar hur en del av kvinnorna i dessa grupper utvecklar en identitet som blivande gravida mammor. För några ter sig detta som ett viktigt första led i att utveckla en föräldraidentitet medan det för andra endast 
blir ett sätt att pröva en identitet eller ett ansvar som sedan överges. Utifrån Baumans (2003) tankegångar blir denna sistnämnda grupp ett exempel på den senmoderna människans behov av att ständigt pröva olika identiteter och relationer utan att för den skull binda upp sig i långvariga åtaganden. Man söker trygghet och täta relationer samtidigt som man värnar den individuella friheten och möjligheten att när som helst lösa upp relationen och gå vidare. Bauman har i ett annat sammanhang talat om "toppocket relationships", en slags relationer som man kan ta fram och luta sig mot när man behöver och sedan stoppa ner när behovet minskar. Kanske kan detta vara ytterligare ett exempel på fenomenet?

För det stora flertalet av mammor som deltar i olika diskussioner på nätet så tycks dock möjligheten att kunna vända sig till andra föräldrar för stöd och erfarenhetsutbyte vara det viktigaste. Ibland beskrivs dessa diskussioner som spontant uppkomna och frukten av ett lite planlöst navigerande mellan olika samtalstrådar, men lika ofta sker det genom att man återkommande söker sig till de samtalstrådar som man tycker är bra dvs där man vet att det finns andra föräldrar som är »bra att prata med». Det behöver inte innebära att man varken har ambitionen att lära känna de andra på tråden eller utveckla en närmare relation. Snarare vill man kunna få bra svar på sina frågor och själv kunna delge sina egna erfarenheter på olika områden.

För en annan grupp mammor har forumdiskussionerna en annorlunda innebörd. De håller sig oftast till en eller väldigt få trådar, söker inte bara erfarenhetsbaserade råd av andra utan också känslomässigt stöd samt lär verkligen känna de personer de träffar på nätet. Ofta träffas de efterhand även utanför internet. Många av de blivande gravida mammorna utgör ett exempel på detta då de umgås på sin tråd och »följer varandra genom glädje och tårarı. Likaså är det för de mammor i materialet som förlorat sina barn. De utvecklar tätare relationer, ger varandra stort stöd och skapar en tydlig och ofta avgränsad grupptillhörighet. Man benämner sig exempelvis ofta som »änglamamma» eller talar om "vi änglamammor, i vår lilla trådı.

Mycket tyder alltså på att dessa diskussioner på nätet genererar en form av socialt kapital för föräldrarna i den meningen att nätgemenskaperna fungerar som en värdefull resurs i föräldraskapet eller föräldrablivandet. Detta oavsett om man skapar nätverk med mer ytliga eller mer personliga relationer. Resonemanget stärks också av Robert Putnams (2000) diskussioner kring hur olika sociala nätverk ges olika betydelse. Putnam skiljer nämligen på två former av nätverk och socialt kapital; det ena benämner han "överbryggande nätverk» (bridging capital) eftersom det baseras på ett ytligare och bredare kontaktnät där man återkommande kan hämta information. Det andra benämner han "sammanbindande nätverk» (bonding capital) då det erbjuder tätare och mer emotionella kontakter (se även Nyqvist, 2005). Dessa mönster stärks också av forskning som studerat kommunikationen på andra sociala nätverksplatser på internet (Ellison et al, 2007; Boyd \& Ellison, 2007).

Men möjligheten att ingå i olika grupper och gemenskaper på nätet tycks inte bara generera ett socialt kapital hos de enskilda 
mammorna utan också, i ett större perspektiv, en diskursiv mångfald kring föräldraskapet. Nästan oavsett vilka önskemål och behov man har så finns det alltid en grupp av likasinnade dit man kan söka sig för att stärka sin identitet och bekräfta sitt föräldraskap. Inte minst föräldrar som avviker från bilden av den heterosexuella känfamiljen eller föräldrar som tar andra vägar än den förväntade upplever detta som befriande. Det gäller alltifrån regnbågsföräldrar, adoptivföräldrar och ensamstående föräldrar till föräldrar som flaskmatar sina barn eller anammar specifika uppfostringsmodeller.

Det stora behovet som vi sett i studien av diskussioner och erfarenhetsbaserad information kan ha flera olika bottnar. Vi har tidigare nämnt Prenskys (2001) och Jenkins (2006) påpekanden om en förändrad medievärld med ökad interaktivitet och en tidig socialisation bort från envägskommunikation. Man vill delge sina erfarenheter och bidra till kunskapsproduktionen på olika sätt. Samtidigt är barn och föräldraskap ett område där många också söker expertkunskap. Det framkom emellertid en oro från mammorna över att mycket av denna expertkunskap endast äger kort giltighet. Nya rön och upptäckter avlöser varandra och i det perspektivet blir det viktigare att kommunicera med personer som har aktuella erfarenheter på området än kanske de egna föräldrarna vars erfarenhet ligger långt tillbaka i tiden. Den stora mängden av tillgänglig information kring föräldraskapet, informationens generella karaktär och den ofta splittrade expertkunskapen visade sig alltså bidra till att många föräldrar istället söker råd från andra föräldrar. Man resignerar inför en svårtolkad ström av generella »fakta» och vänder sig istället till någon i en liknande situation som både kan bidra med erfarenhet och underlätta möjligheten att relatera till den egna situationen. Betydelsen av andras uppdaterade erfarenheter kan alltså sägas öka i takt med att vetenskapen och expertväldet kring barn och föräldraskap fragmenteras. Vilka konsekvenser detta får på sikt för professionella som i sitt dagliga arbete möter föräldrar eller blivande föräldrar återstår att se. Klart är dock att internet är en arena där många föräldrar finns, möts och formar sitt föräldraskap.

\section{Referenser}

Allen, Katherine \& Rainie, Lee (2002) Parents online. Report. Washington: Pew Internet \& American Life Project.

Baum, Lynda. S. (2004) "Internet parent support groups for primary caregivers of a child with special health care needs". Pediatric Nursing, vol. 30, No. 5 pp. 381-388.

Bauman, Zygmunt (2003) Liquid love: On the frailty of human bonds. Cambridge: Polity Press. Beck, Ulrich (2000) Risksamhället. På väg mot en annan modernitet. Göteborg: Daidalos.

Berland GK, Elliott MN, Morales LS, Algazy JI, Kravitz RL, Broder MS, Kanouse DE, Muñoz JA, Puyol JA, Lara M, Watkins KE, Yang H, McGlynn EA. (2001) "Health information on the Internet: accessibility, quality, and reada- 
bility in English and Spanish». JAMA. Vol. 285, No 20, pp. 2612-21.

Bourdieu, Pierre (1988) Homo Academicus. Cambridge: Polity Press.

Boyd, Danah. M. \& Ellison, Nicole. B. (2007) "Social network sites: Definition, history, and scholarship». Journal of Computer-Mediated Communication, Vol, 13, No.1, article 11.

Bremberg, Sven (red) (2004) Nya verktyg för föräldrar - förslag till nya former av föräldrastöd. Statens folhälsoinstitut, 2006:15. Stockholm: Statens folkhälsoinstitut.

Brown, Jennifer Bruning, Winzelberg, Andrew J, Abascal, Liana B \& Taylor, C. B. (2004). "An evaluation of an Internet-delivered eating disorder prevention program for adolescents and their parents". Journal of Adolescent Health, vol. 35, No. 4 s. 290-296.

Bylund, Carma. L. (2005) „Mothers' involvement in decision making during the birthing process: a quantitative analysis of women's online birth stories". Health Communication, vol. 18 No. 1 pp. 23-39.

Bäck-Wiklund, Margareta \& Johansson, Thomas (2003) Nätverksfamiljen. Stockholm: Natur och Kultur.

Capitulo, Kathleen Leask (2004) Perinatal grief online. MCN the American Journal of Maternal Child Nursing, No 5, pp. 305-311.

Carter, Bernie (2007). „Parenting: A glut of information". Journal of Child Health Care, vol. 11, No. 2, pp. 82-84.

Castells, Manuel. (1997) The power of identity. The information age: Economy, society and culture. Volume II. Mass: Blackwell Publications.

Cotten SR, Gupta SS (2004) "Characteristics of online and offline health information seekers and factors that discriminate between them". Social Science \& Medicine, Vol. 59, No. 9, pp. 1795-806.

Daneback, Kristian. (2006). Love and sexuality on the Internet. (Akademisk avhandling, Göteborgs universitet, 2006).

Daneback, Kristian \& Plantin, Lars (2008) "Research on Parenthood and the Internet: Themes and Trends». Cyberpsychology: Jour- nal of Psychosocial Research on Cyberspace, 2(2), article 1. http://cyberpsychology.eu/view. php?cisloclanku=20081 10701\&article=1

Dolev, Rona \& Zeedyk, M. Suzanne (2006). „How to be a good parent in bad times: Constructing parenting advice about terrorism". Child: Care, Health and Development, vol. 32, nr. $4 \mathrm{~s}$. 467-476.

Downing, R. E., Whitehead, T. D., Terre, L. \& Calkins, C. F. (1999). »The Missouri Developmental Disability Resource Center: a Web site responding to the critical need for information of parents with a child with a disability". Behavior Research Methods, Instruments, \& Computers: A Journal of the Psychonomic Society, Inc, vol. 31 No. 2 pp. 292-298.

Drentea, Patricia. \& Moren-Cross, Jennifer. L. (2005) "Social capital and social support on the web: the case of an internet mother siter. Sociology of Health \& Illness, Vol. 27, No.7, pp.920-943.

Dunham, Philip J, Hurshman, Alan, Litwin, Elaine, Gusella, Joanne, Ellsworth, Christine \& Dodd, Peter W. D. (1998). "Computer-Mediated Social Support: Single Young Mothers as a Model System". American Journal of Community Psychology, vol. 26 No. 2, pp. 281-306.

Ellison, Nicole. B., Steinfield, Charles., \& Lampe, Cliff. (2007). "The benefits of Facebook "friends:" Social capital and college students' use of online social network sites". Journal of Computer-Mediated Communication, Vol. 12, No. 4.

Eriksson, Lilly \& Bremberg, Sven (2008) Kartläggning av föräldrars erfarenhet och intresse av föräldrastöd. Stockholm: Statens Folkhälsoinstitut, Oktober 2008

Eurostat (2007) Internet access and e-skills in the EU27 in 2007. Eurostat news release, 166/2007. Retrived 2008-04-08 at www.epp.eurostat. ec.europa.eu.

Fox, Susannah. (2005) Health information online. Report. Washington: Pew Internet \& American Life Project 2005. Retrived 2008-10-09 at www.pewinternet.org

Giddens, Anthony. (1996) Modernitetens följder. Lund Studentlitteratur. 
Hudson, Diane B., Elek, Susan M., Westfall, Joan R., Grabau, Angelynn. \& Fleck, Margaret O. (1999). "Young Parents Project: a 21st-century nursing intervention". Issues in Comprehensive Pediatric Nursing, Vol. 22, No. 4, pp. 153-165.

Hudson, Diane, Brage; Campbell-Grossman, Christie; Fleck, MargaretOfe; Elek, Susan M \& Shipman, Amy (2003). "Effects of the New Fathers Network on first-time fathers' parenting self-efficiency and parenting satisfaction during the transition to parenthood". Issues in Comprehensive Pediatric Nursing, vol. 26, No. 4 pp. 217-229.

Jenkins, Henry. (2006) Convergence Culture. Where old and new media collide. New York: New York University Press.

Johansson, Thomas. (2009) Familjeliv. Malmö: Liber

Lev, Arlene Istar; Gwendolyn Dean; Lauren De Filippis; Kim Evernham; Larin McLaughlin; and Cynthia Phillips (2005). "Dykes and tykes: A virtual lesbian parenting community«. Journal of Lesbian Studies. Special Issue: Lesbian Communities: Festivals, RVs, and the Internet, Vol. 9, No. 1-2, pp. 81-94.

Madge, Clare \& O'Connor, Henrietta (2006). „Parenting Gone Wired: Empowerment of New Mothers on the Internet?"Social \& Cultural Geography, Vol. 7, No. 2, pp. 199-220.

Mankuta, David, Vinker, Shlomo, Shapira, S., Laufer, N. \& Shveiky, D. (2007). "The use of a perinatal internet consultation forum in Israel". BJOG : An International Journal of Obstetrics and Gynaecology, Vol. 114 No. 1, pp. 108-110.

Mazer, Joseph. P., Murphy, Richard. E., \& Simonds, Cheri. J. (2007). "I'll see you on "Facebook:" The effects of computer-mediated teacher self-disclosure on student motivation, affective learning, and classroom climate». Communication Education, Vol 56, No.1, pp. 1-17.

Månsson, Sven-Axel., Söderlind, Peder. (2004) Sexindustrin på nätet. Aktörer, innehåll, relationer och ekonomiska flöden. Malmö: Egalité förlag.

Nicholas, David. B., McNeill, T., Montgomery, G., Stapleford, C. \& McClure, M. (2003) "Communication Features in an Online Group for
Fathers of Children with Spina Bifida: Considerations for Group Development among Men«. Social Work with Groups, Vol. 26, No. 2, pp. 65-80.

Nyqvist, Fredrica. (2005) "Socialt kapital och hälsa - en forskningsöversikt». Socialvetenskaplig tidskrift, $\mathrm{Nr} 1$, sid. 75-89.

O'Connor, Henrietta \& Madge, Clare (2004). „'My mum's thirty years out of date': The role of the Internet in the transition to motherhood" Community, Work \& Family, Vol. 7 No. 3 pp. 351-369.

Plantin, Lars \& Daneback, Kristian (2009) „Parenthood, information and support on the internet. A literature review of research on parents and professionals online». BMC Family Practice 2009, Vol. 10, No. 34. http://www.biomedcentral.com/1471-2296/10/34

Plantin, Lars (2004) „Familj och föräldraskap i förändring. Om mäns föräldraskap i det senmoderna samhället» ur Magnusson, F \& Plantin, L. Mångfald och förändring $i$ socialt arbete. Lund Studentlitteratur.

Prensky, Mark. (2001) "Digital Natives, Digital Immigrants». On the Horizon, Vol. 9. No. 5. pp. 1-6

Putnam, Robert.D. (2000) Bowling Alone: The collapse and Revival of American Community. New York: Simon \& Schuster.

Roman, Christine (2004) Familjen i det moderna. Sociologiska sanningar och feministisk kritik. Malmö: Liber

Russell, Sally (2006). „Netmums: online support for parents". Community Practitioner : The Journal of the Community Practitioners' \& Health Visitors' Association, Vol. 79, No. 2, pp. 44-45.

Sarkadi, Ann (2003). Verklig gemenskap i en virtuell värld? Stockholm: Folkhälsoinstitutet. Rapport 2003:30.

Sarkadi, Ann \& Bremberg, Sven (2005). "Socially unbiased parenting support on the Internet: A cross-sectional study of users of a large Swedish parenting website». Child: Care, Health And Development, Vol. 31, No. 1, pp. 43-52.

SCB (2009) „Moderns och faderns medelålder och 
medianålder för första, andra och tredje barnet

1974-2008", Tabeller över Sveriges befolkning 2008. Stockholm: Statistiska centralbyrån.

Scharer, Kathleen (2005). »Internet Social Support for Parents: The State of Science». Journal of Child and Adolescent Psychiatric Nursing, Vol.
18, No. 1, pp. 26-35.

Ungdomsstyrelsen (2003) Dom kallar oss unga. Stockholm: Ungdomsstyrelsen.

Van Gennep, Arnold (2004) The Rites of Passage.

London: Routledge.

\section{Summary \\ Parenthood and the Internet \\ New meeting places and information channels for late modern parenthood.}

The aim of this study was to address questions about how parents use the Internet to find information and support regarding children, health and family life. Another aim was to find out what this support means for the parents or prospective parents. This was done by means of 18 indepth interviews. All the respondents were women and varied in age between 25 and 39 years. Almost half of the interviewees were first-time parents and nearly all had a university degree.

The study shows that the parents search for both information and social support on the Internet. However, the need for information varied over time and was most intensive in the first and last months of the pregnancy. Many parents also reported they started to search for information and exchange experiences with others in different web communities long before the preg- nancy. Several of these parents developed a collective identity in these groups as "prospective pregnant parents", which seemed to be an important first step in developing a parental identity.

Even though many of the interviewees said they often went in and out different websites and communities, many also reported that they established durable relations with other parents that lasted over many years and also transformed into real-life relationships. This was especially obvious among the mothers who had lost a child, "mothers of angels", but was also a common pattern among the other respondents.

Many of the parents also valued the experience-based information highly, as they regarded much of the parenthood information from different institutions as being too general in character. 